\title{
Molybdenum Oxide Coatings Deposited on Plasma Nitrided Surfaces
}

\author{
Renan Matos Monção ${ }^{a}$, Miguel Rubira Danelon ${ }^{b}$,Larissa Solano de Almeidac, \\ Luciana Sgarbi Rossino ${ }^{b, c}$, Fernanda Roberta Marciano ${ }^{d}$, Thércio Henrique de Carvalho Costa ${ }^{e *}$ (1), \\ Michelle Cequeira Feitor ${ }^{e}$, Ruben Maribondo do Nascimento, \\ Rômulo Ribeiro Magalhães de Sousa ${ }^{a}$ ()
}

${ }^{a}$ Universidade Federal do Piauí, Departamento de Engenharia Mecânica, Teresina, PI, Brasil. ${ }^{b}$ Faculdade de Tecnologia de Sorocaba (FATEC), Sorocaba, SP, Brasil.

'Universidade Federal de São Carlos (UFSCar), Sorocaba, SP, Brasil. ${ }^{d}$ Universidade Federal do Piauí, Departmento de Física, Teresina, PI, Brasil. ${ }^{e}$ Universidade Federal do Rio Grande do Norte, Programa de Pós-graduação em Engenharia Mecânica, Natal, RN, Brasil.

Received: September 16, 2021; Revised: October 01, 2021; Accepted: December 13, 2021

Molybdenum trioxide $\left(\mathrm{MoO}_{3}\right)$ thin films are generally deposit on metallic surfaces to increase their tribological performance. In this manuscript, $\mathrm{MoO}_{\mathrm{x}}$ coatings were for the first time deposited on plasma nitrided surfaces. Vickers microhardness tests, X-ray diffractometry, and micro abrasive wear tests characterized the samples. It was investigated the effect of temperature in hardness and tribological properties of austenitic stainless steel surfaces. When the temperature of plasma nitriding increases, the coating thickness and the nitrogen diffusion on the treated surface also increases, favoring the hardness of the coatings. After $\mathrm{MoO}_{\mathrm{x}}$ deposition, the predominant $\mathrm{MoO}_{3}$ phase with monoclinic and orthorhombic unit cells was observed. $\mathrm{MoO}_{\mathrm{x}}$ coatings after plasma nitriding demonstrated the highest wear resistance.

Keywords: molybdenum oxide, coatings, plasma nitriding; micro abrasive wear.

\section{Introduction}

Molybdenum trioxide $\left(\mathrm{MoO}_{3}\right)$ thin films exhibit highly important optical and electronic properties, permitting their use as gas sensors, lithium-ion batteries, electrochromic device applications, and so on ${ }^{1}$. Orthorhombic $\left(\alpha-\mathrm{MoO}_{3}\right)$ and monoclinic $\left(\beta-\mathrm{MoO}_{3}\right)$ are the major phases; $\alpha-\mathrm{MoO}_{3}$ is the thermodynamically stable and $\beta-\mathrm{MoO}_{3}$ the metastable ${ }^{2}$. Sputtering, chemical vapor deposition, and pulsed laser deposition has been the main techniques for the synthesis of these films. Moreover, heated substrates can extent the crystallinity of the as-deposited thin films ${ }^{3}$. To achieve the ideal stoichiometry, the annealing temperature is above $400{ }^{\circ} \mathrm{C}$ in oxygen-bearing atmospheres ${ }^{4}$. However, the effect of substrate temperature on the stoichiometry and phase purity needs to be discussed in more detail ${ }^{1}$.

Yang ${ }^{5}$ demonstrated the importance of retaining a stable and sufficiently thick $\mathrm{MoO}_{3}$ surface layer to maintain the beneficial effect of Mo on the tribological performance of the coatings. Mo-containing nitride coatings (MoTiN and MoAlTiN) deposited by cathodic arc evaporation were investigated in different conditions [5]. The coatings demonstrated lower friction coefficients and high wear resistance (against WC-6Co and $\mathrm{Si}_{3} \mathrm{~N}_{4}$ balls) compared to their corresponding Mo-free TiN, AlTiN monolithic coatings. However, these coatings

*e-mail: thercioc@hotmail.com showed less improvements in tribological properties when $\mathrm{Al}_{2} \mathrm{O}_{3}$ ball was used ${ }^{5}$.

Besides the wide variety of deposition processes and techniques, $\mathrm{MoO}_{3}$ is generally deposited directly over the metal surface ${ }^{3}$. The deposition of $\mathrm{MoO}_{3}$ on plasma nitrided surfaces has never been performed. Plasma nitriding has been extensively used to improve the hardness, wearresistance, and the tribological stability of metallic surfaces ${ }^{6}$. On temperatures below $450^{\circ} \mathrm{C}$, plasma nitriding is established for conventional coarse-grained austenitic stainless steels and improves corrosion and wear resistance ${ }^{7}$.

In this manuscript, $\mathrm{MoO}_{\mathrm{x}}$ coatings were for the first time deposited on plasma nitrided surfaces. It was investigated the effect of temperature in hardness and tribological properties of austenitic stainless steel surfaces.

\section{Experimental Procedure}

AISI 316 stainless steel substrates $(10 \mathrm{~mm}$ x $10 \mathrm{~mm}$ x $6 \mathrm{~mm})$ were polished to a mirror-like surface. A molybdenum cage was used for $\mathrm{MoO}_{\mathrm{x}}$ deposition. This cage was first polished before deposition and, after, it was sonicated in acetone and dried in hot air jet.

A pulsed source reactor (SDS Plasma) with a maximum voltage of $800 \mathrm{~V}$, using a cylindrical chamber $(400 \mathrm{~mm}$ diameter and $700 \mathrm{~mm}$ height) was used for nitriding and 
$\mathrm{MoO}_{\mathrm{x}}$ deposition. The reactor set up was presented in a previous manuscript ${ }^{8}$. For the conventional plasma nitriding, the samples were placed on an insulating alumina disk, without any cage. Using this setup, the plasma is formed directly on the surface of the samples. For $\mathrm{MoO}_{\mathrm{x}}$ deposition, the molybdenum cage used is in the cathodic potential, producing a hollow cathode effect ${ }^{9}$.

Before plasma nitriding and $\mathrm{MoO}_{\mathrm{x}}$ deposition, the samples were pre-sputtered in $\mathrm{H}_{2}$ : $\mathrm{Ar}(1: 1)$ atmosphere, pressure $150 \mathrm{~Pa}$, and temperature $350{ }^{\circ} \mathrm{C}$ for $1 \mathrm{~h}$ to eliminate contaminants such as oxides and/or grease/fat adsorbed on the surface. The samples were divided into eight groups, and the parameters for plasma nitriding and $\mathrm{MoO}_{3}$ deposition are described in Table 1.

Vickers microhardness tests (ASTM E-384) were performed (Insize microhardness tester, model ISH-TDV 1000) with a diamond indenter using $50 \mathrm{gf}$ and loading of $15 \mathrm{~s}$.

The phase compositions were identified using a highresolution Malvern Panalytical Empyrean X-ray diffractometer (XRD, CoK $\alpha$ radiation, $\lambda=0.1789 \mathrm{~nm}$ ) using Bragg-Brentano reflection geometry. Diffraction spectra were taken from $10^{\circ}$ to $105^{\circ}$ with a step of $0.013^{\circ}$.

The microstructural analyzes were performed according to ASTM E 395-00 norm. Transverse sections were cut, polished to a mirror-like surface, and attacked with aqua regia ( $15 \mathrm{~mL}$ nitric acid $+20 \mathrm{~mL}$ hydrochloric acid $+30 \mathrm{~mL}$ distilled water). The BEL Photonics Technical (MTM-1A) optical microscope performed the cross-sectional images. The semi-quantitative analyses were evaluated using X-ray dispersive energy spectroscopy (EDS) on the Hitachi TM3000 bench-scanning microscope to determine the elements over the sample (point position and line profile).

The micro-abrasive wear tests (MAWTs) were carried out using a fixed ball microwear device. The 52100 steel ball with $25.4 \mathrm{~mm}$ of diameter was used. Each MAWT was performed using $40 \mathrm{~Hz}$ of frequency and a normal load of $8.0 \mathrm{~N}$ for $10 \mathrm{~min}$, without any abrasive or liquid lubricant. The friction coefficient was determined during the test using a load cell ${ }^{10}$. After tests, all the samples were analyzed by optical microscope Leica, model MC170 HD, with camera and software analysis to measure the diameters and crater radio. The wear volume (V) was calculated according to Rutherford and Hutchings's methodology ${ }^{11}$. All MAWTs were carried out in duplicate to ensure good reproducibility.

\section{Results and Discussion}

Figure 1 shows the cross-sectional optical microscopy from the samples. It's possible to see the microstructures of each treated surface (regular and homogeneous topography). The thickness of each coating is shown in Table 2.

When the temperature increases, the coating thickness also increases ${ }^{12}$. In CPN400 sample (Figure 1a), it's seen

Table 1. Main parameters used for plasma nitriding and $\mathrm{MoO}_{x}$ deposition.

\begin{tabular}{|c|c|c|c|c|c|c|}
\hline \multirow[t]{2}{*}{ Samples } & \multicolumn{3}{|c|}{$\begin{array}{c}\text { Conventional plasma nitriding } \\
\left.\text { (Gas flow: } 50 \% \mathrm{H}_{2}+25 \% \mathrm{~N}_{2}+25 \% \mathrm{Ar}\right)\end{array}$} & \multicolumn{3}{|c|}{$\mathrm{MoO}_{\mathrm{x}}$ deposition (Gas flow: $50 \% \mathrm{H}_{2}+50 \% \mathrm{O}_{2}$ ) } \\
\hline & Pressure & Time & Temperature & Pressure & Time & Temperature \\
\hline AISI 316 & - & - & - & - & - & - \\
\hline CPN400 & $300 \mathrm{~Pa}$ & $4 \mathrm{~h}$ & $400^{\circ} \mathrm{C}$ & - & - & - \\
\hline CPN450 & $300 \mathrm{~Pa}$ & $4 \mathrm{~h}$ & $450{ }^{\circ} \mathrm{C}$ & - & - & - \\
\hline CPN500 & $300 \mathrm{~Pa}$ & $4 \mathrm{~h}$ & $500^{\circ} \mathrm{C}$ & - & - & - \\
\hline $\mathrm{MoO}_{\mathrm{x}}$ & - & - & - & $100 \mathrm{~Pa}$ & $4 \mathrm{~h}$ & $400^{\circ} \mathrm{C}$ \\
\hline $\mathrm{CPN} 400+\mathrm{MoO}_{\mathrm{x}}$ & $300 \mathrm{~Pa}$ & $4 \mathrm{~h}$ & $400^{\circ} \mathrm{C}$ & $100 \mathrm{~Pa}$ & $4 \mathrm{~h}$ & $400^{\circ} \mathrm{C}$ \\
\hline $\mathrm{CPN} 450+\mathrm{MoO}_{\mathrm{x}}$ & $300 \mathrm{~Pa}$ & $4 \mathrm{~h}$ & $450^{\circ} \mathrm{C}$ & $100 \mathrm{~Pa}$ & $4 \mathrm{~h}$ & $400{ }^{\circ} \mathrm{C}$ \\
\hline $\mathrm{CPN}^{200}+\mathrm{MoO}_{\mathrm{x}}$ & $300 \mathrm{~Pa}$ & $4 \mathrm{~h}$ & $500{ }^{\circ} \mathrm{C}$ & $100 \mathrm{~Pa}$ & $4 \mathrm{~h}$ & $400{ }^{\circ} \mathrm{C}$ \\
\hline
\end{tabular}

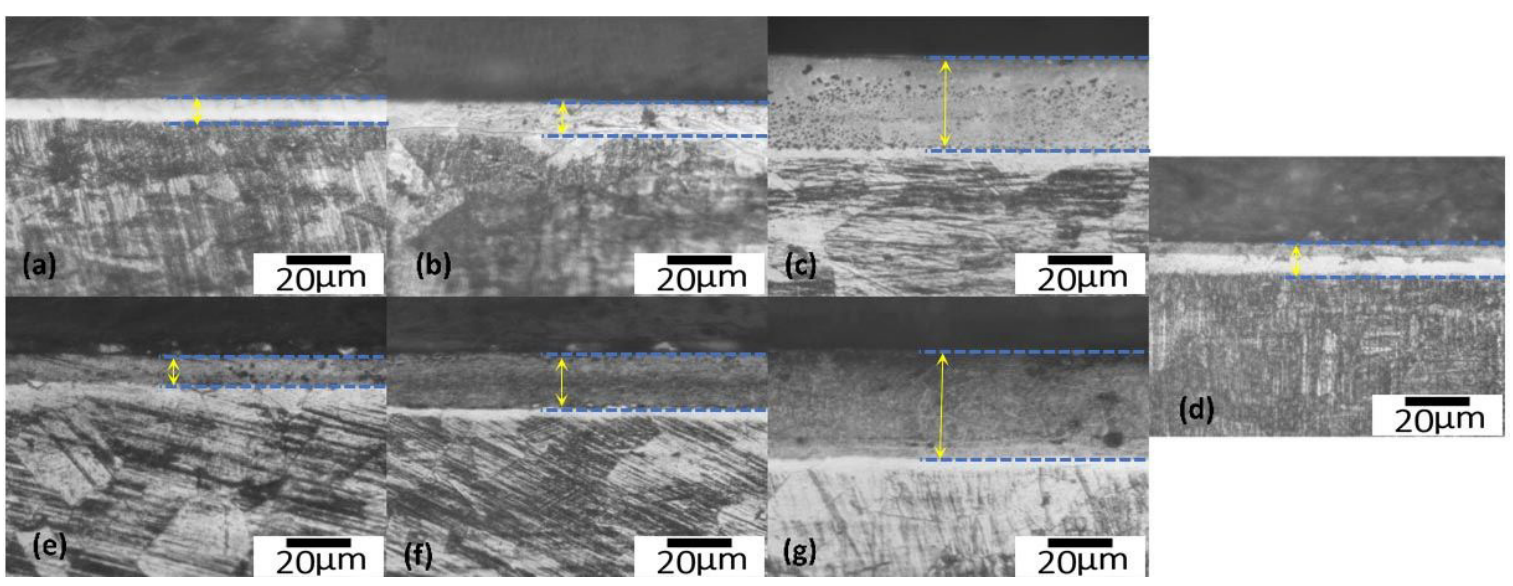

Figure 1. Cross-sectional optical microscopy from (a) CPN400, (b) CPN450, (c) CPN500, (d) $\mathrm{MoO}_{x}$, (e) $\mathrm{CPN} 400+\mathrm{MoO}_{x}$, (f) $\mathrm{CPN}_{450}+\mathrm{MoO}_{x}$ and (g) CPN500+MoO ${ }_{x}$ samples. 
the formation of a thin and homogeneous layer, with white color. The expanded austenite and iron nitride alloyed layer formed is dense and has the precipitation of free white surface layers $^{13}$. When the temperature increases (CPN450 sample, Figure 1b), starts the precipitation of a darkness phase (chrome nitride) in the formed layer, which becomes predominant at $500{ }^{\circ} \mathrm{C}$ (CPN500 sample, Figure 1c).

At lower temperatures, there's the formation of a thinner nitrided layer with nitrogen saturation on the surface, whose $\mathrm{wt} \% \mathrm{~N}$ drops abruptly along with the thickness of the formed layer (Table 3). As the temperature increases, the diffusion coefficient increases, favoring nitrogen diffusion in stainless steel, which increases the layer thickness and $\mathrm{wt} \% \mathrm{~N}$ along with the treated layer (Table 3). Thus, high temperatures, such as $500{ }^{\circ} \mathrm{C}$, provide lower $\mathrm{wt} \% \mathrm{~N}$ on the surface of the layer, which remains at greater depths, resulting in a thicker and harder layer and the depth of the formed layer. This directly reflects the hardness values of the formed layer (Figure 2). With increasing temperature and greater nitrogen diffusion on the treated surface, in addition to the increase in thickness, the formation of hard phases such as chromium nitride is favored, increasing the hardness of the layer $^{12}$. Table 4 shows the surface microhardness values

Table 2. Minimum, maximum and mean thickness values from the coatings. Each mean corresponds to the average of 5 different measurements.

\begin{tabular}{cccc}
\hline Samples & $\begin{array}{c}\text { Minimum } \\
(\mu \mathrm{m})\end{array}$ & $\begin{array}{c}\text { Maximum } \\
(\mu \mathrm{m})\end{array}$ & Mean $(\mu \mathrm{m})$ \\
\hline $\mathrm{CPN400}$ & 11.86 & 13.79 & $12.52+0.84$ \\
\hline $\mathrm{CPN} 450$ & 16.54 & 19.58 & $17.81+1.21$ \\
\hline $\mathrm{CPN500}$ & 50.46 & 51.84 & $51.23+0.71$ \\
\hline $\mathrm{MoO}_{3}$ & 15.44 & 16.13 & $15.78+0.25$ \\
\hline $\mathrm{CPN} 400+\mathrm{MoO}_{\mathrm{x}}$ & 13.51 & 14.89 & $14.12+0.60$ \\
\hline $\mathrm{CPN} 450+\mathrm{MoO}_{\mathrm{x}}$ & 33.92 & 35.57 & $34.69+0.66$ \\
\hline $\mathrm{CPN500+ \textrm {MoO } _ { \mathrm { x } }}$ & 63.14 & 65.44 & $64.57+0.84$ \\
\hline
\end{tabular}

Table 3. Quantity of nitrogen (by wt $\%$ ) at the interface points of the nitride samples. The position of the point is determined from the surface edge (point 1) towards the substrate with 0.006 coordinate advances.

\begin{tabular}{cccc}
\hline Points & CPN400 & CPN450 & CPN500 \\
\hline Point 1 & 4.6 & 7.3 & 6.4 \\
\hline Point 2 & 0.7 & 0.4 & 4.4 \\
\hline Point 3 & 0.0 & 0.0 & 5.6 \\
\hline Point 4 & 0.0 & 0.0 & 5.2 \\
\hline
\end{tabular}

Table 4. Surface microhardness values of AISI 316 stainless steel after plasma nitriding and $\mathrm{MoO}_{3}$ deposition.

\begin{tabular}{cc}
\hline Samples & Vickers Hardness (HV) \\
\hline AISI 316 & 230.0 \\
\hline CPN400 & 1421.4 \\
\hline CPN450 & 1514.8 \\
\hline $\mathrm{CPN500}$ & 1812.3 \\
\hline $\mathrm{MoO}_{3}$ & 868.0 \\
\hline $\mathrm{CPN} 400+\mathrm{MoO}_{\mathrm{x}}$ & 995.3 \\
\hline $\mathrm{CPN} 450+\mathrm{MoO}_{\mathrm{x}}$ & 865.4 \\
\hline $\mathrm{CPN500+ \textrm {MoO } _ { \mathrm { x } }}$ & 816.6 \\
\hline
\end{tabular}

according to the treatment received. Diamond indenter generally induces a massive plastic deformation, causing fracture $^{14}$. Surface hardness up to $1800 \mathrm{HV}$ was achieved from plasma nitriding. The surface hardness is related to treatment parameters. Increasing temperature increases surface hardness ${ }^{13}$.

Figure 3 shows the line profile of the $\mathrm{CPN} 400+\mathrm{MoO}$ sample using EDS. The microstructural analysis determined the elements over the sample, showing the duplex treatment (nitriding $+\mathrm{MoO}_{\mathrm{x}}$ deposition).

Figure 4 shows the XRD diffractograms of the samples according to the treatment received. The formation of chromium nitride in the coating appeared more intensely at $450{ }^{\circ} \mathrm{C}$ and $500{ }^{\circ} \mathrm{C}$. High temperatures favor the formation of chromium nitride in the formed layer, whose phase is hard and fragile, presenting low resistance to wear and corrosion ${ }^{12,15}$. It is expected that the formation of precipitates in the diffusion zone increases surface hardness and leads to superior fatigue resistance ${ }^{16}$. Ion nitriding causes surface hardening due to diffusion of $\mathrm{Cr}_{\mathrm{x}} \mathrm{N}$ and $\mathrm{Fe}_{\mathrm{x}} \mathrm{N}$ into ferrous and non-ferrous metallic surfaces, promoting a diffuse zone and oxide and compound layers ${ }^{17}$. After $\mathrm{MoO}_{\mathrm{x}}$ deposition (Figure 4b), the predominant formation of the $\mathrm{MoO}_{3}$ phase with the monoclinic and orthorhombic unit cell was observed, with $\mathrm{Mo}_{8} \mathrm{O}_{23}$ and the combination of molybdenum and substrate, forming the $\mathrm{Fe}_{9.7} \mathrm{Mo}_{0.3}$ phase.

Figure 5 shows the results of the micro-abrasive wear tests on the samples. There is an increase in wear resistance for all

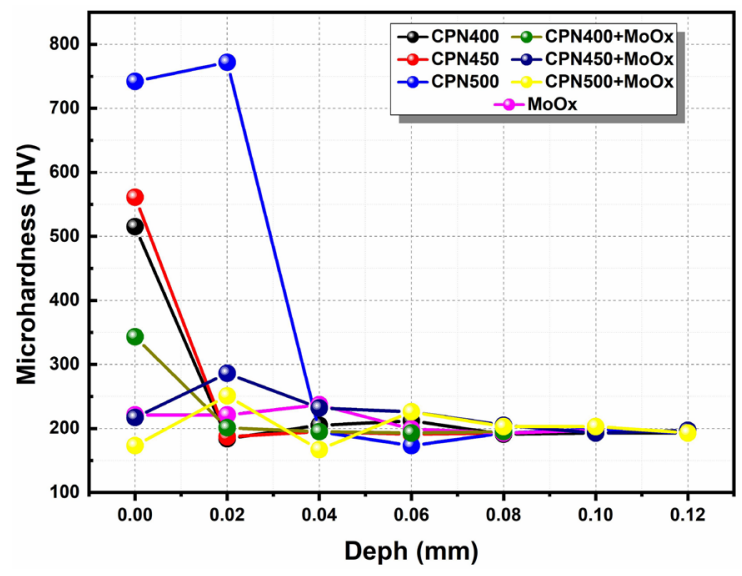

Figure 2. Microhardness values as a function of the layer thickness and the treatment received.

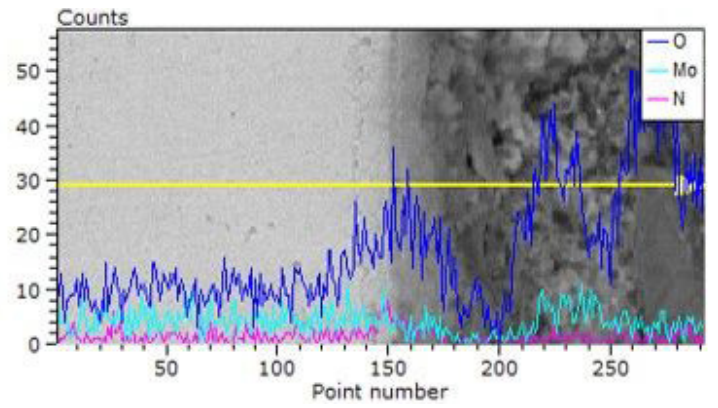

Figure 3. Line profile of $\mathrm{CPN} 400+\mathrm{MoO}_{x}$ sample by EDS. 

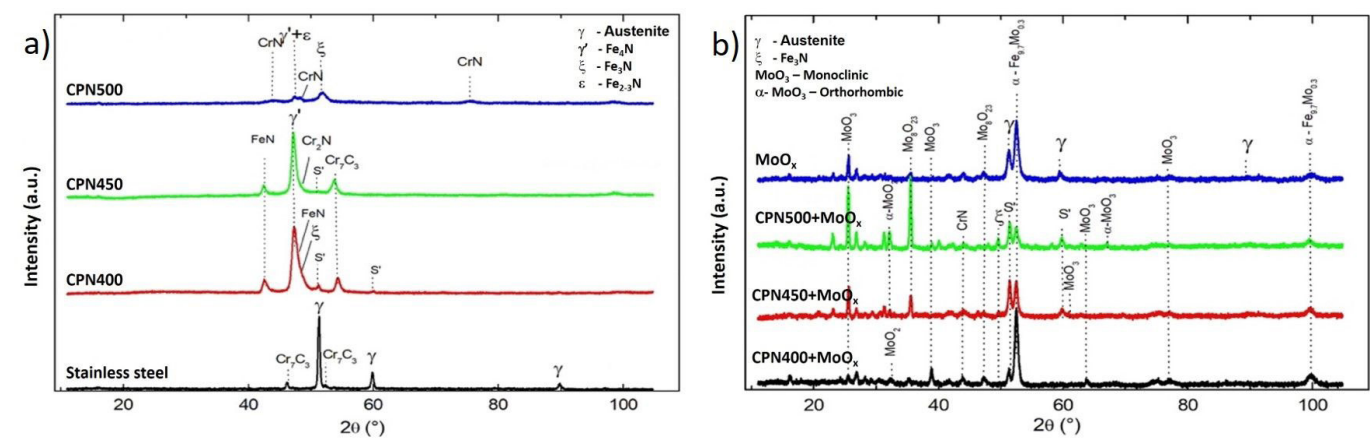

Figure 4. X-ray diffractograms after (a) nitriding and (b) nitriding $+\mathrm{MoO}_{\mathrm{x}}$ deposition.

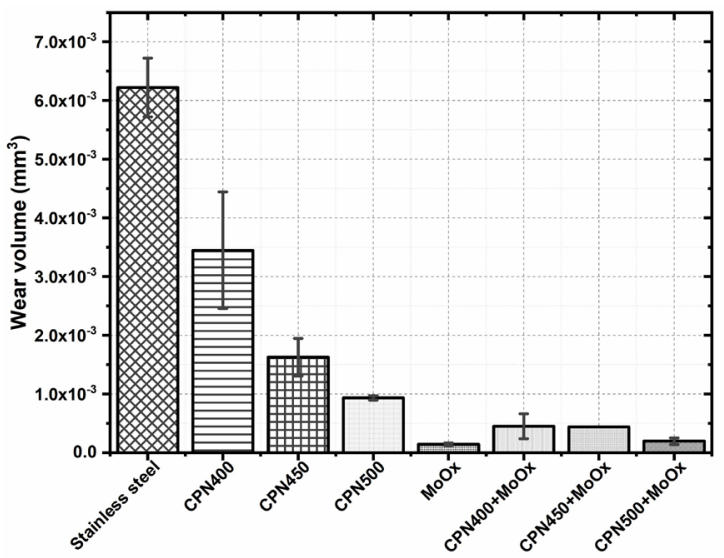

Figure 5. Wear volume calculated after micro-abrasive tests.
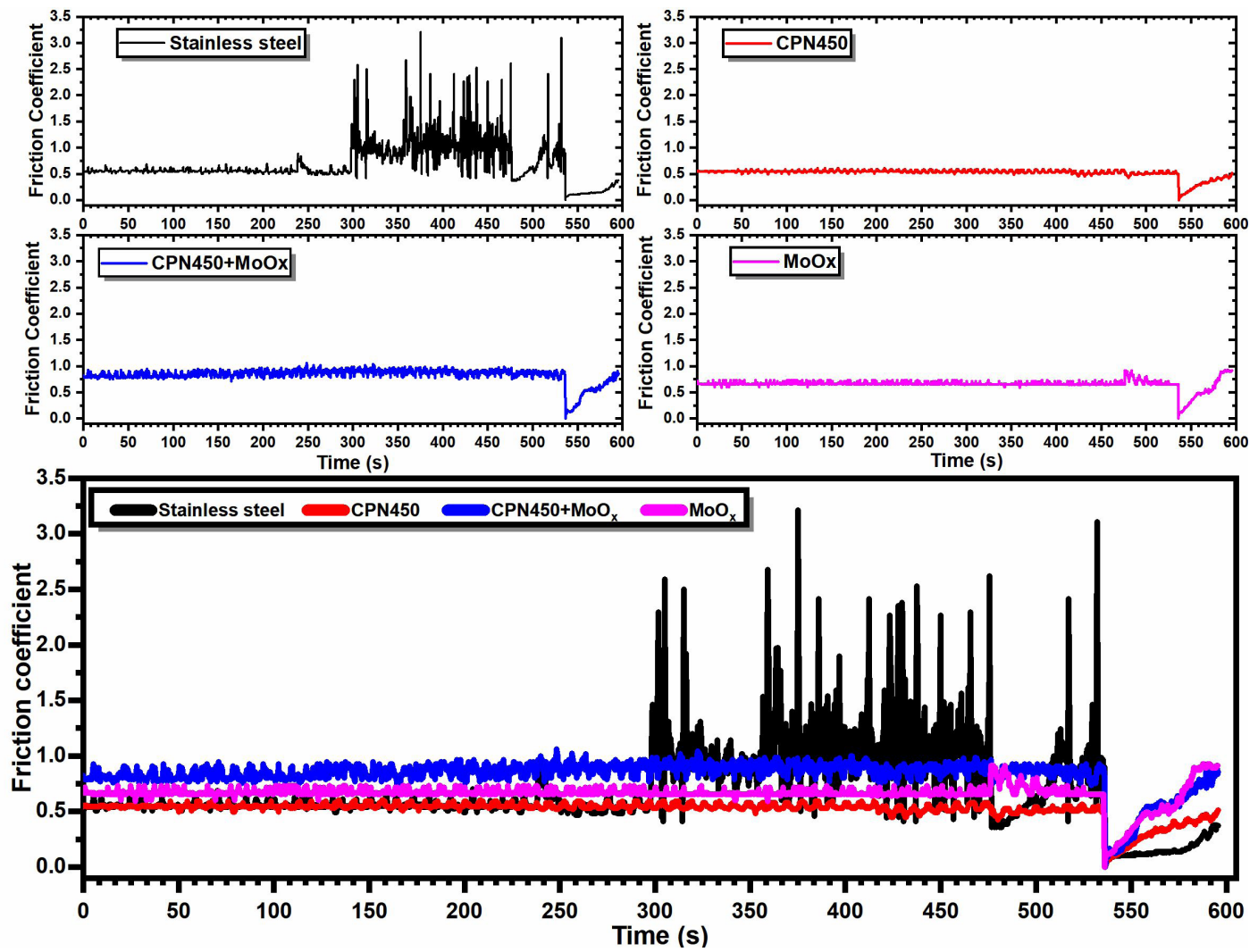

Figure 6. Friction coefficients of the samples. 

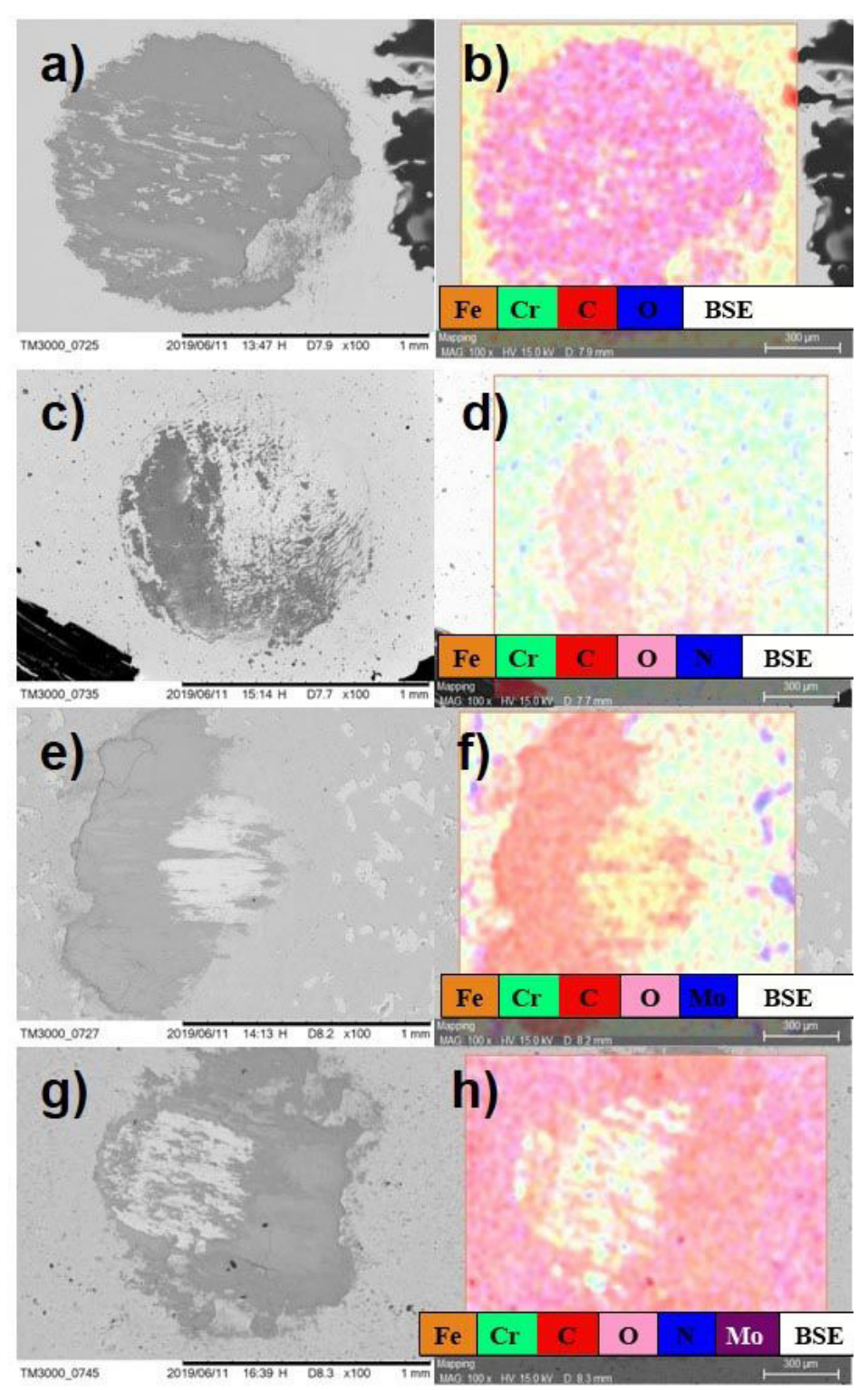

Figure 7. Wear crater with EDS analysis of (a-b) stainless steel, (c-d) CPN400, (e-f) $\mathrm{MoO}_{\mathrm{x}}$ and (g-h) CPN400 $+\mathrm{MoO}_{\mathrm{x}}$

treated materials compared to stainless steel, demonstrating the effectiveness of the treatment performed. Also, it is observed that the wear resistance is not directly related to the hardness of the formed layer ${ }^{18,19}$. Although the $\mathrm{MoO}_{\mathrm{x}}$ sample did not have the highest hardness value among the treated materials, this was the condition of the highest wear resistance. The wear volume was almost the same for all nitriding $+\mathrm{MoO}_{\mathrm{x}}$ deposition samples. The worst wear resistance was on the CPN400 sample, due to the small layer thickness formed.

Figure 6 shows that the friction coefficients of the treated samples are similar. The increase in the stainless steel friction coefficient at the end of the test is justified by the greater wear volume suffered by this material, which promotes the formation of oxidized wear debris over the crater as illustrated in Figure 7(a) and confirmed in Figure 7(b), increasing the material removed and friction coefficient throughout the test.
As observed in Figure 7(c-d), the formation of the wear debris of the nitrided material is lower than all treated materials, justifying your lower friction coefficient. It is possible to observe, in Figure $7(\mathrm{e}-\mathrm{f})$ and (g-h) significant wear oxidized debris formation in the materials with $\mathrm{MoO}_{x}$ films that remain around the crater.

\section{Conclusion}

In this manuscript, $\mathrm{MoO}_{\mathrm{x}}$ coatings were for the first time deposited on plasma nitrided surfaces. When the temperature of the plasma nitriding increases, the coating thickness also increases. The temperature also increases the nitrogen diffusion on the treated surface, favoring the hardness of the coatings. After $\mathrm{MoO}_{\mathrm{x}}$ deposition, the predominant $\mathrm{MoO}_{3}$ phase with monoclinic and orthorhombic unit cells was observed. $\mathrm{MoO}_{x}$ coatings after plasma nitriding demonstrated the highest 
wear resistance. This manuscript showed that the combined treatments (nitriding $+\mathrm{MoO}_{\mathrm{x}}$ deposition) increased the surface hardness and the wear resistance of the metallic substrates, amplifying their use as tribological protective coatings.

\section{Acknowledgments}

F.R.M. and R.R.M.S. would like to thank to National Council for Scientific and Technological Development, CNPq, for the grants (304133/2017-5 to FRM and 407288/2018-0 to RRMS).

\section{References}

1. Ramana CV, Atuchin VV, Kesler VG, Kochubey VA, Pokrovsky LD, Shutthanandan V, et al. Growth and surface characterization of sputter-deposited molybdenum oxide thin films. Appl Surf Sci. 2007;253(12):5368-74.

2. Balendhran S, Walia S, Nili H, Ou JZ, Zhuiykov S, Kaner RB, et al. Semiconductors: two-dimensional molybdenum trioxide and dichalcogenides. Adv Funct Mater. 2013;23(32):3946.

3. Ramana CV, Julien CM. Chemical and electrochemical properties of molybdenum oxide thin films prepared by reactive pulsedlaser assisted deposition. Chem Phys Lett. 2006;428(1):114-8.

4. Soultati A, Vasilopoulou M, Papadimitropoulos G, Douvas A, Kostis I, Karystinos I, et al. Impact of microwave post-deposition annealing on the crystallization of amorphous hydrogenated perovskites. The case of the three-dimensional tungsten and of the two-dimensional molybdenum oxide films. Thin Solid Films. 2016;615:329-37.

5. Yang Q. Wear resistance and solid lubricity of molybdenumcontaining nitride coatings deposited by cathodic arc evaporation. Surf Coat Tech. 2017;332:283-95.

6. Miyamoto J, Abraha P. The effect of plasma nitriding treatment time on the tribological properties of the AISI H13 tool steel. Surf Coat Tech. 2019;375:15-21.

7. Ura-Bińczyk E, Krawczyńska A, Sitek R, Lewandowska M. Mechanical properties and corrosion resistance of hydrostatically extruded 316 LVM stainless steel after low-temperature plasma nitriding. Surf Coat Tech. 2019;375:565-72.

8. Alves C, Araújo FO, Ribeiro KJB, Costa JAP, Sousa RRM, Sousa RS. Use of cathodic cage in plasma nitriding. Surf Coat Tech. 2006;201(6):2450-4.
9. Naeem M, Iqbal J, Zakaullah M, Shafiq M, Mujahid ZI, DíazGuillén JC, et al. Enhanced wear and corrosion resistance of AISI-304 steel by duplex cathodic cage plasma treatment. Surf Coat Tech. 2019;375:34-45.

10. Santos WC, Pereira JO No, Silva RO, Rodriguês G, Moreto JA, Manfrinato MD, et al. Desenvolvimento de dispositivo e estudo do comportamento ao microdesgaste abrasivo do aço AISI 420 temperado e revenido. Matéria. 2015;20(2):304-315.

11. Rutherford KL, Hutchings IM. A micro-abrasive wear test, with particular application to coated systems. Surf Coat Tech. 1996;79(1):231-9.

12. Pereira JO No, Silva ROd, Silva EH, Moreto JA, Bandeira $\mathrm{RM}$, Manfrinato MD, et al. Wear and corrosion study of plasma nitriding F53 super duplex stainless steel \%. Mater Res. 2016;19:1241-52.

13. Thaiwatthana S, Li XY, Dong H, Bell T. Comparison studies on properties of nitrogen and carbon $\mathrm{S}$ phase on low temperature plasma alloyed AISI 316 stainless steel. Surf Eng. 2002;18(6):4337.

14. Dalibon EL, Pecina JN, Cabo A, Trava-Airoldi VJ, Brühl SP. Fretting wear resistance of DLC hard coatings deposited on nitrided martensitic stainless steel. Journal of Materials Research and Technology. 2019;8(1):259-66.

15. Araújo Ed, Bandeira RM, Manfrinato MD, Moreto JA, Borges $\mathrm{R}$, Vales SS, et al. Effect of ionic plasma nitriding process on the corrosion and micro-abrasive wear behavior of AISI 316L austenitic and AISI 470 super-ferritic stainless steels. Journal of Materials Research and Technology. 2019;8(2):2180-91.

16. Naeem M, Shafiq M, Zaka-ul-Islam M, Bashir MI, Díaz-Guillén JC, Lopez-Badillo CM, et al. Novel duplex cathodic cage plasma nitriding of non-alloyed steel using aluminum and austenite steel cathodic cages. J Alloys Compd. 2017;721:307-11.

17. Gontijo LC, Machado R, Miola EJ, Casteletti LC, Nascente PAP. Characterization of plasma-nitrided iron by XRD, SEM and XPS. Surf Coat Tech. 2004;183(1):10-7.

18. Lopes HSM, Moreto JA, Manfrinato MD, Cruz NCd, Rangel EC, Rossino LS. Micro abrasive wear behaviour study of carburization and ion plasma nitriding of P20 steel \%. Mater Res. 2016;19:686-94.

19. Rosa AGA, Moreto JA, Manfrinato MD, Rossino LS. Study on friction and wear behavior of SAE 1045 steel, reinforced nylon 6.6 and NBR rubber used in clutch disks \%. Mater Res. 2014;17:1397-403. 